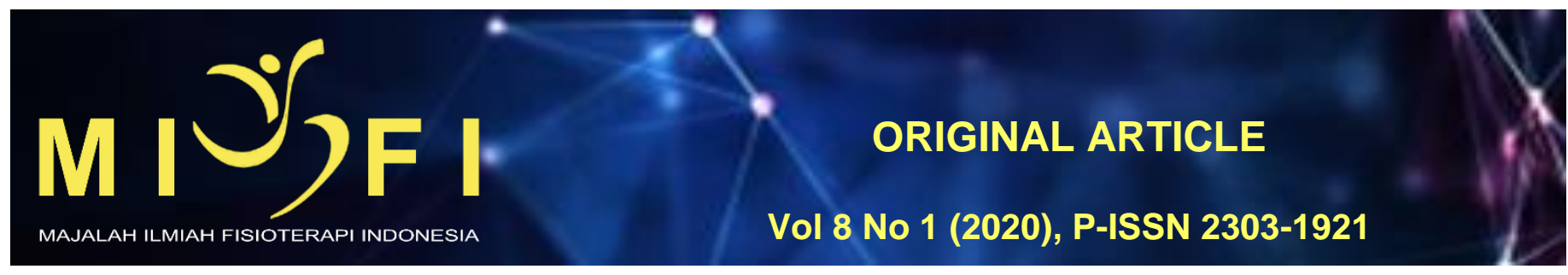

\title{
HUBUNGAN ANTARA TINGKAT AKTIVITAS FISIK TERHADAP KEMAMPUAN MEMORI JANGKA PENDEK MAHASISWI PROGRAM STUDI FISIOTERAPI, FAKULTAS KEDOKTERAN, UNIVERSITAS UDAYANA
}

\author{
Ni Luh Nopi Andayani ${ }^{1}$, Made Hendra Satria Nugraha ${ }^{2}$ \\ 1,2 Departemen Fisioterapi, Fakultas Kedokteran, Universitas Udayana \\ nopiandayanifk@unud.ac.id
}

\begin{abstract}
ABSTRAK
Mahasiswa tidak terlepas dari kegiatan belajar dan mengingat. Memori digunakan untuk menyimpan informasi dari proses belajar dan informasi tersebut dapat digunakan kembali di masa yang mendatang. Penelitian terdahulu menjelaskan mengenai manfaat aktivitas fisik dalam hal merangsang neurogenesis, memfasilitasi metabolisme neurotransmitter, serta menjaga dan meningkatkan stimulasi molekuler dan seluler di otak yang mendukung terjadinya plastisitas otak. Tujuan dari penelitian ini adalah untuk mengetahui hubungan tingkat aktivitas fisik terhadap kemampuan memori jangka pendek mahasiswi program studi fisioterapi, fakultas kedokteran, universitas udayana. Penelitian ini dilaksanakan bulan April - Mei 2019 dengan desain studi cross sectional analytic. Sampel pada penelitian ini menggunakan simple random sampling dengan jumlah sampel mencapai 61 mahasiswi. Hasil penelitian menunjukan bahwa terdapat hubungan bermakna positif antara tingkat aktivitas fisik dengan memori jangka pendek dengan $p=0,003$ $(p<0,05)$ dengan koefisien korelasi sebesar 0,375 . Hal ini berarti bahwa terdapat hubungan yang cukup, signifikan, dan searah antara aktivitas fisik dengan memori jangka pendek pada mahasiswi program studi fisioterapi FK Unud yaitu semakin tinggi tingkat aktivitas fisik seseorang maka semakin tinggi pula kemampuan memori jangka pendeknya.

Kata kunci: aktivitas fisik, memori jangka pendek, mahasiswi
\end{abstract}

\section{THE RELATIONSHIP BETWEEN PHYSICAL ACTIVITY LEVEL AND SHORT-TERM MEMORY IN STUDENTS AT PHYSIOTHERAPY STUDY PROGRAM, MEDICAL FACULTY, UDAYANA UNIVERSITY}

\begin{abstract}
Students are inseparable from learning and remembering activities. Memory is used to store information that has been obtained from the learning process and the information can be reused in the future. Previous research explains the benefits of physical activity in terms of stimulating neurogenesis, facilitating neurotransmitter metabolism, and maintaining and increasing molecular and cellular stimulation in the brain that supports brain plasticity. The purpose of this study was to determine the relationship between the level of physical activity and the short-term memory skills of a physiotherapy study program student, medical faculty, udayana university. This research was conducted in April - May 2019 with a cross sectional analytic study design. Samples were taken using simple random sampling with a total sample of 61 female students. The results showed that there was a positive significant relationship between the level of physical activity with short-term memory with $p=0.003(p<0.05)$ with a coefficient correlation of 0.375 . This means that there is a sufficient, significant, and directional relationship between physical activity and short-term memory in physiotherapy study program students, the higher the level of physical activity, the higher the ability of short-term memory.
\end{abstract}

Keywords: physical activity, short-term memory, student 


\section{PENDAHULUAN}

Mahasiswa tidak terlepas dari kegiatan belajar dan mengingat. Memori digunakan untuk menyimpan informasi dari proses pembelajaran dan informasi tersebut dapat digunakan kembali di masa yang mendatang. Berdasarkan waktunya, memori dapat diklasifikasikan menjadi tiga yaitu: memori jangka pendek, menengah, dan panjang. Memori jangka pendek memiliki peran dalam hal pemahaman bahasa dan pemecahan masalah. Selain itu, aktivasi memori jangka pendek juga menentukan kecepatan proses kognitif. Proses kognitif yang baik diperlukan oleh mahasiswa fisioterapi dalam hal memahami materi saat proses pembelajaran sehingga dapat menunjang kemajuan prestasi belajar mahasiswa melalui indeks prestasi kumulatif. ${ }^{1}$

Memori dapat dipengaruhi oleh berbagai faktor seperti fisiologi, psikologis, dan patologis, diantaranya: usia, jenis makanan, kemampuan berkonsentrasi, hormonal, tingkat aktivitas fisik, jenis kelamin, gen, dan lain-lain. ${ }^{2}$ Beberapa penelitian terdahulu menjelaskan bahwa tingkat aktivitas fisik dan latihan fisik berpengaruh terhadap fungsi otak. Hal disebabkan aktivitas fisik dapat menjaga aliran darah yang adekuat serta meningkatkan nutrisi ke otak. Peran lain dari aktivitas fisik yaitu menghasilkan faktor tropik yang merangsang neurogenesis, memfasilitasi metabolisme neurotransmitter, serta menjaga dan meningkatkan stimulasi molekuler dan seluler di otak yang mendukung terjadinya plastisitas otak. ${ }^{3}$

Berdasarkan riset kesehatan dasar tahun 2013, tingkat aktivitas fisik penduduk Indonesia masih tergolong rendah dan memiliki pola hidup sedentari (kurang bergerak). Hasil uji pada siswa menunjukkan bahwa sebesar $45 \%$ tingkat kebugaran kurang. Kondisi tersebut menyebabkan daya tahan tubuh kurang yang dapat berdampak pada penurunan prestasi belajar. Masalah kesehatan seperti pre-diabetes di usia muda, penurunan fungsi kognitif seperti memori kerja, motivasi, dan konsentrasi dapat muncul akibat tingkat aktivitas fisik yang rendah. Peneliti terdahulu menyatakan bahwa penurunan kosentrasi dan ketidakmampuan melakukan pekerjaan secara bersamaan berkaitan dengan tingkat aktivitas fisik yang rendah. ${ }^{4}$ Penelitian yang dilakukan ingin membuktikan bahwa keterkaitan antara tingkat aktivitas fisik dapat berpengaruh terhadap kemampuan memori jangka pendek. Hal ini dikarenakan memori jangka pendek adalah tempat untuk mengolah informasi baru yang memiliki kapasitas terbatas dan bertahan dalam waktu singkat. ${ }^{5}$

\section{METODE}

Penelitian dilaksanakan pada bulan April - Mei 2019 dengan jenis penelitian observasional analitik dengan studi cross sectional. Sampel ditentukan sesuai dengan kriteria inklusi dan eksklusi secara random sampling dan diperoleh sebanyak 62 sampel. Pengukuran variabel dependent tingkat aktivitas fisik menggunakan International Physical Activity Questionnaires (IPAQ) sementara variabel independent memori jangka pendek menggunakan Wechsler Adult Intelligence Scale (WAIS) dengan digit span test. Data yang didapat kemudian dianalisis menggunakan SPSS.

\section{HASIL \\ Karakteristik Responden}

Pada penelitian ini yang menjadi responden yaitu mahasiswi fisioterapi yang berusia 21-23 tahun dengan pengambilan sampel secara simple random yang telah memenuhi kriteria inklusi dan eksklusi dan didapatkan 61 responden. Adapun karakteristik responden berdasarkan usia, aktivitas fisik, dan memori jangka pendek dapat dilihat pada tabel berikut ini:

Tabel 1. Karakteristik Sampel

Berdasarkan Usia, Tingkat Aktivitas Fisik, dan Memori Jangka Pendek

\begin{tabular}{ll}
\hline Data & Mean \pm StandarDeviasi \\
\hline Usia & $22,21 \pm 0,86$ \\
Aktivitas Fisik & $5,30 \pm 337$ \\
Memori Jangka Pendek & $12,67 \pm 1,89$ \\
\hline
\end{tabular}

Berdasarkan tabel 1 dari 61 mahasiswi menunjukan bahwa responden berusia $(22,21 \pm 0,86)$ tahun dan $100 \%$ berjenis kelamin perempuan.

\section{Uji Normalitas}

Untuk menentukan uji statistik yang digunakan dalam menguji hipotesis, maka dilakukan uji normalitas terlebih dahulu. Uji normalitas pada penelitian ini tertera pada tabel 2 berikut.

\begin{tabular}{ll} 
Tabel 2 Uji Normalitas & Kolmogrof-Smirnov \\
\hline Variabel & Signifikan \\
\hline Aktivitas Fisik & 0,200 \\
Memori Jangka Pendek & 0,000 \\
\hline
\end{tabular}

Berdasarkan tabel 2 uji normalitas Kolmogrof-Smirnov bahwa didapat aktivitas fisik $(p>0,05)$ yang diinterpretasikan bahwa data berdistribusi normal, sedangkan untuk memori jangka pendek $(p<0,05)$ sehingga data tidak berdistribusi normal. Maka, uji hipotesis yang digunakan adalah uji non-parametrik.

\section{Uji Hipotesis Hubungan Tingkat Aktivitas Flsik terhadap Kemampuan Memori Jangka Pendek}

Analisis data yang digunakan untuk mengetahui hubungan tingkat aktivitas fisik dengan kemampuan memori jangka pendek yaitu menggunakan analisis statistik non-parametrik sperman rho. Hasil uji analisis ini dapat dilihat pada tabel 3 berikut : 
Tabel 3 Hubungan Tingkat Aktivitas Flsik terhadap Kemampuan Memori Jangka Pendek

\begin{tabular}{lll}
\hline Korelasi Variabel & Reabilitas (Rs) & $\mathbf{p}$ \\
\hline Aktivitas fisik dengan memori jangka pendek & 0,375 & 0,003
\end{tabular}

Berdasarkan Tabel 3 menunjukan bahwa terdapat hubungan bermakna positif antara tingkat aktivitas fisik dengan memori jangka pendek $(p<0,05)$ dengan koefisien korelasi sebesar 0,375 . Hal ini berarti bahwa terdapat hubungan yang cukup, signifikan, dan searah antara aktivitas fisik dengan memori jangka pendek pada mahasiswi program studi fisioterapi FK Unud yaitu semakin tinggi tingkat aktivitas fisik seseorang maka semakin tinggi pula kemampuan memori jangka pendeknya.

\section{DISKUSI}

Tingkat aktivitas fisik penduduk Indonesia masih tergolong rendah dan memiliki pola hidup sedentari (kurang bergerak). Hasil uji pada siswa menunjukkan bahwa sebesar $45 \%$ tingkat kebugaran kurang. Kondisi tersebut menyebabkan daya tahan tubuh kurang yang dapat berdampak pada penurunan prestasi belajar. Masalah kesehatan seperti pre-diabetes di usia muda, penurunan fungsi kognitif seperti memori kerja, motivasi, dan konsentrasi dapat muncul akibat tingkat aktivitas fisik yang rendah. Hasil penelitian menunjukkan bahwa terdapat hubungan bermakna positif antara tingkat aktivitas fisik dengan memori jangka pendek $(p<0,05)$ dengan koefisien korelasi sebesar 0,375 . Hal ini berarti bahwa terdapat hubungan yang cukup, signifikan, dan searah antara aktivitas fisik dengan memori jangka pendek pada mahasiswi program studi fisioterapi FK Unud yaitu semakin tinggi tingkat aktivitas fisik seseorang maka semakin tinggi pula kemampuan memori jangka pendeknya. Hal ini didukung oleh penelitian terdahulu menyatakan bahwa penurunan kosentrasi dan ketidakmampuan melakukan pekerjaan secara bersamaan berkaitan dengan tingkat aktivitas fisik yang rendah. ${ }^{4}$ Penelitian lainnya membuktikan bahwa keterkaitan antara tingkat aktivitas fisik dapat berpengaruh terhadap kemampuan memori jangka pendek. ${ }^{5}$

Memori jangka pendek menjadi sarana dalam mengelola informasi baru dan bertahan dalam waktu yang singkat. Tahapan dalam pemrosesan memori jangka pendek meliputi: tahapan pemasukan pesan dalam hal pemilahan dan pengkodean informasi yang masuk, dilanjutkan ke tahapan penyimpanan, dan proses mengingat kembali (recall). Seorang mahasiswa tidak dapat mengingat sebagian materi dikarenakan kapasitas memori jangka pendek yang terbatas serta perhatian yang kurang. Pengulangan sangatlah penting agar informasi penting tidak hilang. Memori jangka pendek akan mendukung aktivitas mahaiswa seperti berkomunikasi dan memahami pembicaraan serta bahan bacaan. Dengan memiliki kemampuan memori jangka pendek yang baik mahasiswa dapat mempertahankan informasi yang dibutuhkan. Sebaliknya apabila kemampuan memori jangka pendek terganggu, maka proses mengingat informasi akan terganggu pula dan berujung kepada penurunan prestasi belajar. ${ }^{5}$

\section{DAFTAR PUSTAKA}

1. Pratiwi, SE. Handoko, W. dan Rahmatania, R. 2016. Pengaruh Senam Otak terhadap Memori Jangka Pendek Mahasiswa. Jurnal Vokasi Kesehatan: 2(1); 1 - 9

2. Susanto,Y., Djojosoewarno, P., dan Rosnaeni. 2009. Pengaruh Olahraga Ringan Terhadap Memori Jangka Pendek Pada Wanita Dewasa. JKM: 8(2): 144-150

3. Wahyuni, A dan Nisa K. 2016. Pengaruh Aktivitas dan Latihan Fisik terhadap Fungsi Kognitif pada Penderita Demensia. Majority: 5(4): $12-16$

4. Junaidi, MC dan Soegiarto, B. 2016. Hubungan antara Aktivitas Fisik terhadap Memori Kerja Murid SMA Don Bosco III Bekasi. Sari Pediatri: 18(4)

5. Putri, DR. 2018. Pengaruh Depresi Terhadap Kemampuan Memori Jangka Pendek pada Remaja (Skripsi). Malang: UMM

6. Kramer AF \& Erickson KI. Capitalizing on cortical plasticity: influence of physical activity on cognition and brain function. TRENDS in Cognitive Sciences. 2007; 11(8): 344-348.

7. Yaffe K, Barnes D, Nevitt M, Li-Yung Lui, Covinsky K., 2001. A Prospective study of physical activity and cognitive decline in elderly women who walk. Arch Intern Med,161:1703-1708

8. Cotman C. W, Berchtold N. C. 2002. Exercise: A Behavior intervention to enhance brain health and plasticity. Trends in Neurosciences, 25(6) : 295-300

9. Muzamil, MS, Afriwardi, dan Martini, RD. 2014. Hubungan Antara Tingkat Aktivitas Fisik dengan Fungsi Kognitif pada Usila di Kelurahan Jati Kecamatan Padang Timur. Jurnal Kesehatan Andalas: 3(2) 